\title{
Genetic characteristics reflecting the population size and disturbance regime of Siebold's beech (Fagus crenata Blume) populations at the northernmost distribution
}

\author{
By M. Kobayashi ${ }^{1), *}$, K. Kitamura ${ }^{2)}$, T. MATsui ${ }^{2)}$ and S. KaWANO ${ }^{3)}$ \\ Echigo-Matsunoyama Museum of Natural Science, Tokamachi, Niigata 942-1411, Japan
}

(Received $15^{\text {th }}$ January 2012)

\begin{abstract}
To understand the population dynamics of tree populations at the range limit of a species' range, it is important to determine which population size and disturbance regime are critical to genetic diversity. Siebold's beech (Fagus crenata Blume) is a major canopy tree species of cool-temperate forests in Japan, with the northernmost distribution reaching the Kuromatsunai Depression in southwestern Hokkaido, Japan. We examined the genetic variation and dynamics of three beech forests, with different disturbance history and population attributions in the northernmost population. The Tsubamenosawa (TSU) and Sannosuke (SAN), both natural forest, have historically experienced little artificial disturbance, whereas the Soibetsu (SOI), a secondary forest, was intensively logged, and thus strongly disturbed in the past. In total, 35 alleles were detected among 12 loci, encoding 9 enzyme systems. At TSU, $H e$ and $R S$ were 0.141 and 2.280 , respectively. At SAN, $H e$ and $R S$ were 0.142 and 2.604 , respectively. At SOI were 0.182 and 2.628, respectively. Parameters of genetic diversity changed with population size, small isolated population indicated low values. Gene flow distance for low density mature trees in the natural forests was greater than that for high-density secondary forest. However, effective population sizes $(\mathrm{Ne})$ were $34.7,64.3$ and 60.3 in TSU, SAN and SOI, respectively, reflecting differences in the density of mature individuals. The results suggested that the population with the low density of mature trees kept genetic diversity through long distance gene flow. The mature tree density affected the effective population size in the northernmost beech populations.
\end{abstract}

Key words: allozyme, population size, disturbance regime, Fagus crenata, range limit.

\section{Introduction}

Siebold's beech (Fagus crenata Blume) is one of the widely distributed canopy tree species in cool-temperate

\footnotetext{
1) Graduate School of Environmental Earth Science, Hokkaido University, Sapporo 060-0810, Japan.

2) Dept. of Plant Ecology, Forestry and Forest Products Research Institute, Matsunosato 1, Tsukuba, Ibaraki, 305-8687, Japan.

3) Professor Emeritus, Department of Botany, Graduate School of Science, Kyoto University, Kyoto 606-8502, Japan. Present address: 303-204 Greentown Makishima, Motoyashiki 51-1, Uji, Kyoto 611-0041, Japan.

*) Author for correspondence: Maкото KoвaYaSHI. Echigo-Matsunoyama Museum of Natural Science, 1712-2, Matsunoyamamatsukuchi, Tokamachi, Niigata 942-1411, Japan. Tel: +81-25595-8311, Fax: +81-25-595-8320. E-mail: mkobayan@gmail.com
}

forests of Japan. The northern range limit of Siebold's beech is in the Kuromatsunai Depression, Oshima Peninsula in southwestern Hokkaido (TATEWAKI, 1958). This region is the boundary between typical cool-temperate forests dominated by beech and pan-mixed forests consisting of deciduous hardwood species, with evergreen coniferous species (TATEWAKI, 1958). Palynological studies indicate that beech forests began to extend its range northward after the last glacial period at approximately $12,000 \mathrm{yr}$ B.P., expanding its range at the present northern front between 350 and 680 yr B.P. (IGARASHI, 1994; TAKIYA and HAGIWARA, 1997; KITO and TAKIмото, 1999; KIто, 2003).

Phytogeographical studies using genetic techniques and analyses have demonstrated geographical genetic diversity in plant species. Intraspecific allozyme variation in Siebold's beech has been examined for northeastern populations (NAGANO et al., 1990; NAGANO and NASU, 1991; TAKAHASHI et al., 1994) and populations throughout the species' distributional range (TOMARU et al., 1997). TAKAHASHI et al. (1994) investigated genetic variations in beech populations in Hokkaido and northern Honshu, and found that some alleles were absent in Hokkaido. TOMARU et al. (1997) studied genetic diversity in 23 beech populations over the species' geographical distribution, and revealed that within-population genetic variation was higher than among-population differentiation. Despite low genetic differentiation among populations, significant correlations have been found between the average expected heterozygosity, and both the latitudinal and longitudinal distributions of the populations (TOMARU et al., 1997).

TAKAHASHI et al. (1994) examined the genetic variation of 14 beech populations in Hokkaido and northern Honshu. The genetic compositions of Honshu and Hokkaido populations were shown to be essentially the same, except for five rare alleles that were absent in the Hokkaido populations. This fact suggests that Hokkaido populations may have experienced a bottleneck or an effect of isolation from those in Honshu. TAKAHASHI $e t$ al. (2002) suggested that a weak genetic structure in the northern marginal beech population at the Utasai beech forest was attributable to an insufficient number of generations to reach a quasi-stationary genetic structure. Comps et al. (2001) investigated the genetic variation of 12 polymorphic isozyme loci in European beech populations (Fagus sylvatica L.) throughout the species' range. Maximum allelic richness was estimated to occur in the southeastern part of the range (southern Italy and the 
Balkans), where beech was isolated and survived during the last Ice Age. They also reported that the levels of heterozygosity were lower in the populations in refugia than those in recently colonized regions.

Several small isolated beech populations with low density of beech were located at the distribution front area (TATEWAKI, 1958). The decrease of genetic diversity is expected in these areas. And, when populations are exposed to natural or artificial disturbances, changes in habitat conditions will result in changes in population size and structure. The knowledge on the levels of genetic dynamics in marginal populations of a species' geographical range may contribute to the understanding of the maintenance or expansion mechanisms of the plant population in general. In order to understand the influence of population size and disturbance regime to genetic parameters in the northernmost beech populations, we investigated the difference in the genetic diversity parameters of three populations located at the northernmost distribution of the range in Oshima Peninsula, Hokkaido: two natural isolated beech forest populations that have experienced few artificial disturbances, and another population that has been exposed to severe artificial disturbance.

\section{Materials and Methods}

\section{Study sites and sample collections}

The study was conducted at the northern range limit of beech forests at Tsubamenosawa (TSU), Sannosuke (SAN) and Soibetsu (SOI) in Oshima Peninsula, southwestern Hokkaido in Japan (Fig. 1). TSU beech forest, the northernmost isolated natural population of Siebold's beech (Fagus crenata), is located on a steep northwestern slope of Mt. Horobetsu at an elevation of 520-620 m. The canopy layer of the TSU forest is domi- nated by Siebold's beech and an oak, Quercus crispula, with low frequencies of Tilia japonica, Acer mono, Betula ermanii, Magnolia hypoleuca, and Sorbus commixta. The forest floor is mainly dominated by Sasa kurilensis, Daphniphyllum humile, and Cephalotaxus harringtonia. Many seedlings and juveniles of Siebold's beech occurred at this site (KOBAYASHI and WATANABE, 2003). The area of beech distribution is about 3-ha.

The SAN beech forest is one of the northernmost isolated natural beech populations, on a steep northwestern slope of Mt. Horobetsu at an elevation of about 500 $\mathrm{m}$. The canopy layer of the SAN forest is dominated by Siebold's beech, and subdominant tree species are Quercus crispla, Abies sachalinensis, Tilia japonica, Acer mono, Betula ermanii, Magnolia hypoleuca, and Sorbus commixta. The area of beech distribution is about 27.5-ha, larger than TSU forest.

The SOI beech stand was a secondary forest that has been logged once approximately 80 years before; since then, it has regenerated naturally. This forest stand established on the plateau at an elevation of approximately $100 \mathrm{~m}$ above sea level in the Kuromatsunai Depression. The canopy layer of the forests at SOI was dominated by Siebold's beech, with low frequencies of several deciduous trees such as Quercus crispula, Tilia japonica, Betula ermanii, Acer mono, and Magnolia hypoleuca. The forest floor is dominated by Sasa kurilensis, Daphyniphyllum humile and Skimmia japonica. The area of beech distribution is 100-ha or more.

We have been monitoring beech phenology in this region since 2005. During this period, we observed flowering in trees greater than at least $20 \mathrm{~cm}$ in $\mathrm{DBH}$. Thus, we consider individuals of $\mathrm{DBH}>20 \mathrm{~cm}$ as mature trees. We established one $10 \times 50 \mathrm{~m}$ transect in the beech forests at TSU, SAN and SOI. The locations of all beech trees within transects were recorded and mapped,

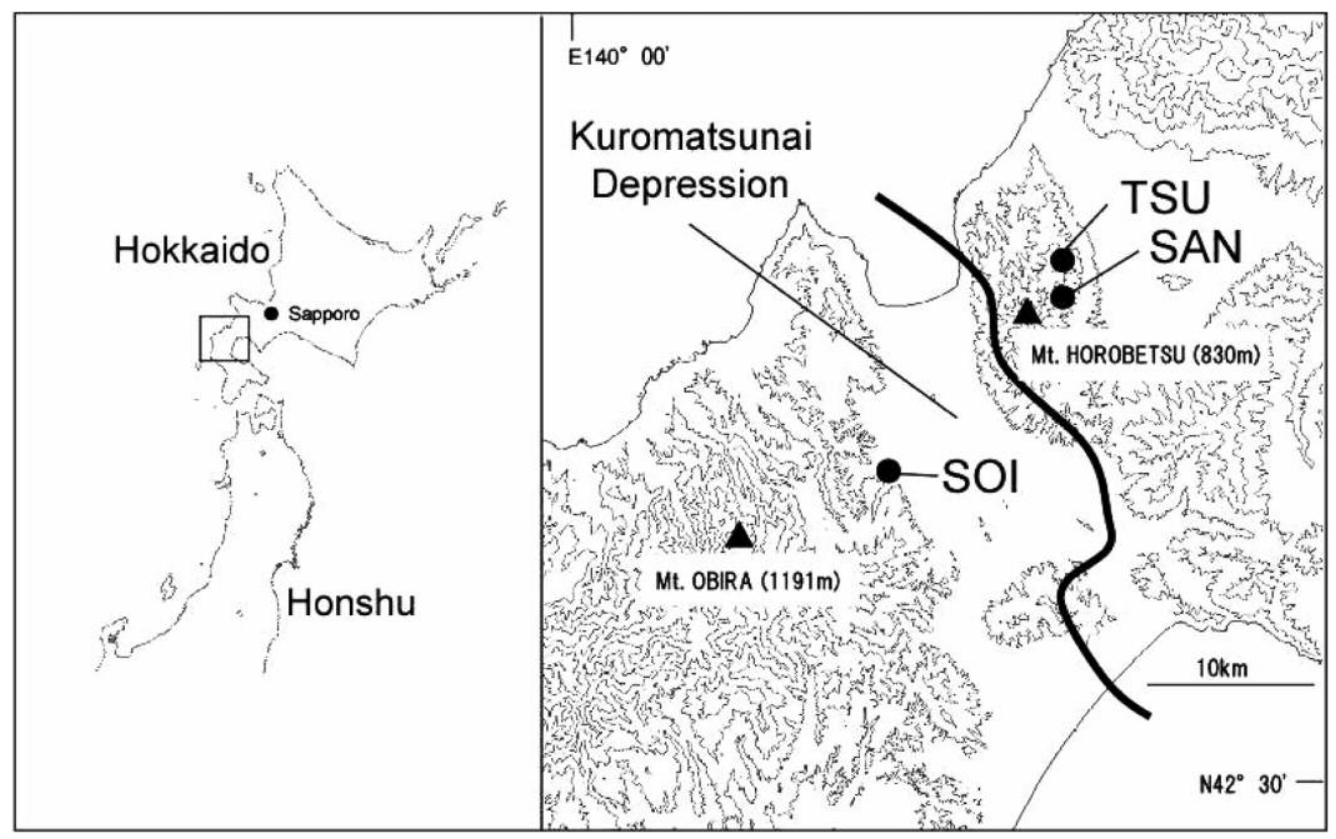

Figure 1. - Location of the three study sites. The solid line indicates the northern frontier of continuous beech forest in the Kuromatunai Depression (KITO, 2003). However, small patches or low density mixed beech forest stands have been observed beyond this northern limit (TATEWAKI, 1958). Tsubamenosawa and Sannosuke beech population represents one of these small patch populations. 
and the diameter at breast (or ground) height (DBH or DGH for trees $<1.3 \mathrm{~m}$ tall) was measured. We collected several fresh leaves from all individuals within two study plots in August 2005 (TSU and SOI) and July 2008 (SAN) for allozyme analysis. In addition, we sampled all mature trees $(20 \mathrm{~cm} \leq \mathrm{DBH})$ in the neighboring 3 -ha area at TSU in September 2005. In April 2006, we collected winter buds from 108 mature beech trees within the neighboring 100-ha area at SOI, using a lattice sampling design: a 100-m interval grid was laid out, and all of the individuals closest to each grid intersection

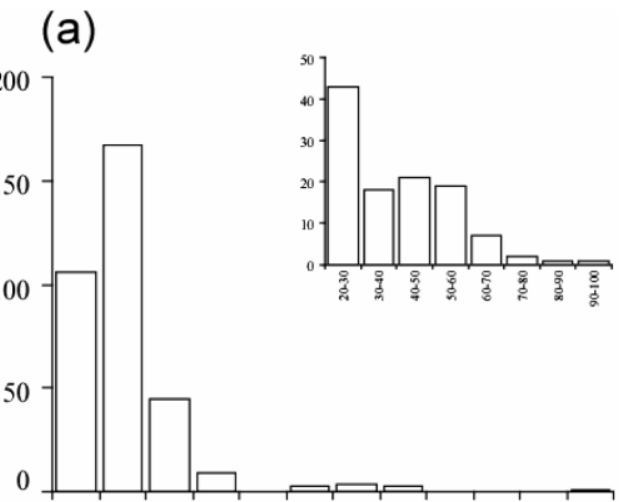

(b)

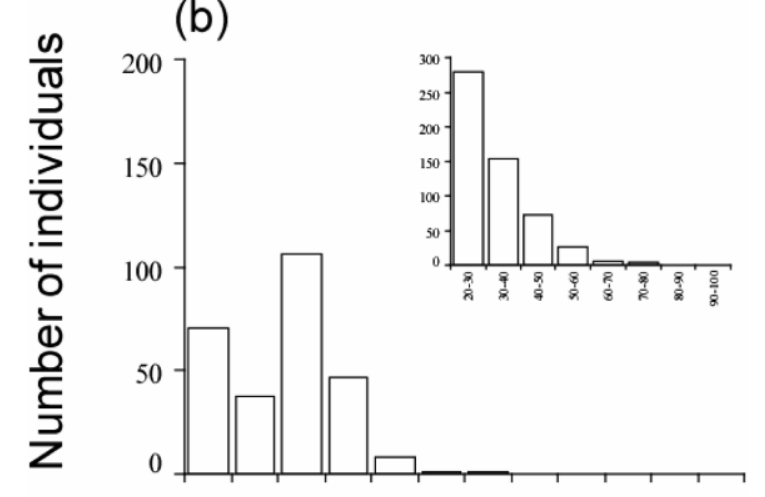

(c)

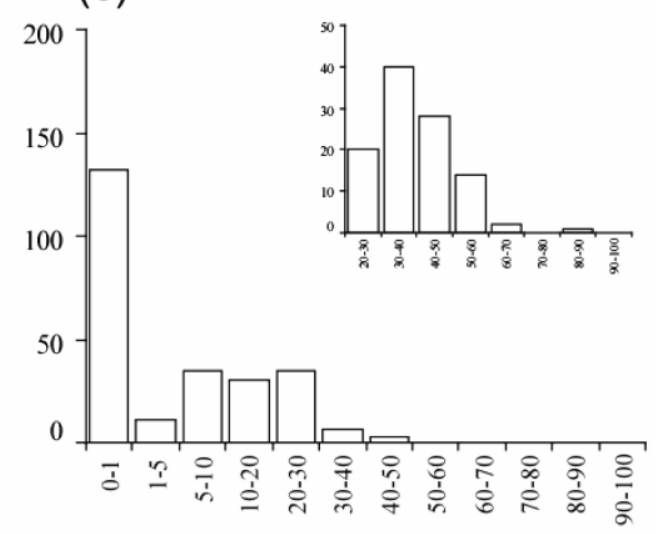

\section{Diameter}

Figure 2. - Histograms showing the size-class structures of populations at the three study sites. We measured the diameters at ground level (DGH) for individuals $<1.3 \mathrm{~m}$ tall; all other measurements are diameter at breast height (DBH). (a) Tsubamenosawa (TSU); (b) Sannosuke (SAN); (c) Soibetsu (SOI). Upper right histogram of each histogram shows the size-class structures of mature trees at the three study sites. were sampled. In August 2008, we sampled all mature trees in the neighboring 27.5-ha area at SAN. These samples were kept at low temperature, taken into the laboratory, and stored in a deep freezer at $-80^{\circ} \mathrm{C}$ until enzymes were extracted.

The size class (diameter) distribution differed among TSU, SAN and SOI (Fig. 2). The size class distribution at TSU was L-shaped, with the highest peak in the 1-5 cm class; the maximum DBH was $92.4 \mathrm{~cm}$ (Fig. 2). SAN had a mode at $5-10 \mathrm{~cm}$ class, and maximum DBH was $46.5 \mathrm{~cm}$. The size class distribution of mature trees (DBH $>20 \mathrm{~cm}$ ) at SAN was clear L-shaped distribution (Fig. 2). SOI had a mode in the smallest size class (diameter $<1 \mathrm{~cm}$ ), minor peaks in the $5-10 \mathrm{~cm}$ and 20-30 cm classes, and the maximum DBH was $47.7 \mathrm{~cm}$ (Fig. 2).

Approximately $100 \mathrm{mg}$ of sample tissue was frozen in liquid nitrogen and crushed, using a mortar and pestle. Immediately after crushing, $1 \mathrm{~mL}$ of extraction buffer (0.1 M Tris-HCL at pH 7.5, 25\% glycerol, $1 \%$ Tween 80 , $10 \mathrm{mM}$ DTT, $1 \%$ 2-mercaptoethanol) and $70 \mathrm{mg}$ of polyvinylpolypyrrolidone were added (Shiraishi 1988). After centrifugation at $20,000 \times g$ at $4^{\circ} \mathrm{C}$ for $10 \mathrm{~min}$, $16 \mu \mathrm{L}$ of supernatant was used per enzyme for vertical discontinuous polyacrylamide slab gel electrophoresis (DAVIS, 1964; ORSTEIN, 1964).

The following 12 loci encoding 9 enzyme systems were analyzed: alanine aminopeptidase (Aap), amylase (Amy1 and Amy2), diaphorase (Dia), fumarase (Fum), glutamate dehydrogenase $(G d h)$, glutamate oxaloacetate transaminase (Got1 and Got3), 6-phosphogluconate dehydrogenase $(6 p g)$, phosphoglucoisomerase (Pgi) and phosphoglucomutase (Pgm1 and Pgm2).

\section{Data analyses}

The expected heterozygosity (He; NEI, 1987) and allelic richness (Rs; MousAdIK and PETIT, 1996) were calculated using the computer program FSTAT ver. 2.9 (GOUDET, 2002) for populations and size classes.

Spatial substructure was analyzed by spatial autocorrelation using Moran's I (MORAN, 1950; SOKAL and ODEN, 1978a, b; Duncan and Stewart, 1991), using the computer program PSAwinD ver. 1.1.1 (TAKAHASHI, 2003) at a distance class of $10 \mathrm{~m}$ intervals.

To evaluate gene flow distance by pollen and seed, we used CERVUS software (MARSHALL et al., 1998; SLATE $e t$ al., 2000), which is a maximum likelihood program designed for use with co-dominant markers, to estimate possible candidate parents of seedlings $(\mathrm{DGH}<1 \mathrm{~cm})$ from the log-likelihood ratios (LOD scores) based on seedling and parent genotypes. Because CERVUS was developed for microsatellite markers, we used a mutation rate of zero. We have chosen the two individuals with the highest LOD scores as parent candidates. Based on distances from the designated juveniles, the closer candidate was regarded as the seed parent, and the other as the pollen parent.

We calculated the effective population size $(\mathrm{Ne})$ from the density of mature trees $(\mathrm{DBH}>20 \mathrm{~cm}$ : we checked flowering tree size by field observation) in each population, the outcrossing rate (Muona, 1990; KAWANO and 
KITAMURA, 1997), and the area centered on an individual within which $86.5 \%$ of the parents were detected (CRAWFORD, 1984; SILVERSTOWN and LOVETT-DOUST, 1993).

\section{Results}

\section{Genetic variability}

In total, 35 alleles were detected among 12 loci encoding 9 enzyme systems. Amy 1 was fixed for three popula-

Table 1. - Allele frequencies at Tsubamenosawa (TSU), Sannosuke (SAN) and Soibetsu (SOI).

\begin{tabular}{|c|c|c|c|c|}
\hline locus & allele & TSU & SAN & SOI \\
\hline \multirow[t]{2}{*}{$6 p g$} & $a$ & - & - & 0.004 \\
\hline & $b$ & 1.000 & 1.000 & 0.996 \\
\hline \multirow[t]{3}{*}{ Aap } & $z$ & - & 0.002 & - \\
\hline & $a$ & 0.969 & 0.973 & 0.958 \\
\hline & $b$ & 0.031 & 0.025 & 0.042 \\
\hline Amyl & $b$ & 1.000 & 1.000 & 1.000 \\
\hline \multirow[t]{5}{*}{ Amy 2} & $b$ & 0.006 & 0.004 & 0.006 \\
\hline & $c$ & 0.531 & 0.408 & 0.462 \\
\hline & $d$ & - & 0.010 & 0.004 \\
\hline & $e$ & 0.458 & 0.559 & 0.528 \\
\hline & $f$ & 0.004 & 0.019 & 0.000 \\
\hline \multirow[t]{3}{*}{ Dia } & $b$ & 0.010 & 0.049 & 0.076 \\
\hline & $c$ & 0.969 & 0.941 & 0.918 \\
\hline & $d$ & 0.021 & 0.010 & 0.006 \\
\hline \multirow[t]{2}{*}{ Fum } & $a$ & 0.352 & 0.324 & 0.362 \\
\hline & $b$ & 0.648 & 0.676 & 0.638 \\
\hline \multirow[t]{3}{*}{$G d h$} & $\bar{a}$ & - & 0.002 & 0.002 \\
\hline & $b$ & 1.000 & 0.996 & 0.998 \\
\hline & $c$ & - & 0.002 & - \\
\hline \multirow[t]{4}{*}{ Gotl } & $a$ & - & 0.002 & 0.002 \\
\hline & $b$ & 0.006 & 0.010 & 0.010 \\
\hline & $c$ & 0.993 & 0.988 & 0.970 \\
\hline & $d$ & 0.001 & - & 0.018 \\
\hline \multirow[t]{2}{*}{ Got3 } & $b$ & - & - & 0.004 \\
\hline & $c$ & 1.000 & 1.000 & 0.996 \\
\hline \multirow[t]{5}{*}{$P g i$} & $b$ & 0.001 & - & 0.010 \\
\hline & $c$ & - & 0.004 & 0.004 \\
\hline & $d$ & 0.815 & 0.970 & 0.888 \\
\hline & $e$ & 0.182 & 0.027 & 0.098 \\
\hline & $z$ & 0.001 & - & - \\
\hline \multirow[t]{2}{*}{ Pgm1 } & $\bar{a}$ & 0.985 & 0.982 & 0.992 \\
\hline & $b$ & 0.015 & 0.018 & 0.008 \\
\hline \multirow[t]{3}{*}{ Pgm2 } & $b$ & 0.009 & 0.010 & - \\
\hline & $c$ & 0.940 & 0.808 & 0.500 \\
\hline & $d$ & 0.051 & 0.183 & 0.500 \\
\hline
\end{tabular}

tions. The remaining 10 loci at SOI had more than two alleles. In contrast, at SAN and TSU, 8 loci had more than two alleles and locus of 6pg and Got3 (SA) and locus of $6 p g, G d h$ and Got3 were fixed (Table 1).

The calculated genetic parameters of $\mathrm{Pl}, \mathrm{He}$ and $\mathrm{Rs}$ for the entire population at TSU were $0.67,0.141$ and 2.28 , respectively (Table 2). At SAN were $0.75,0.142$ and 2.604, respectively (Table 2). At SOI were $0.92,0.182$ and 2.628, respectively (Table 2).

\section{Spatial genetic structure}

We used the most frequent allele at each locus to calculate Moran's I at 10-m intervals (Table 3). Moran's I indicated significant positive values within the $0-10 \mathrm{~m}$ distance class for six loci at SOI, five loci at SAN and two loci at TSU (Table 3). The number of significant positive values decreased in the 10-20 m distance class for three transects. The value decreased with distance, indicating that genetic similarity decreases with distance. The number of significant positive values of Moran's $I$

Table 2. - The number of samples and genetic parameters at three study sites, Tsubamenosawa (TSU), Sannosuke (SAN) and Soibetsu (SOI).

\begin{tabular}{cccc}
\hline & TSU & SAN & SOI \\
\hline $\mathrm{N} 1$ & 338 & 238 & 252 \\
$\mathrm{~N} 2$ & 246 & 555 & 108 \\
$P l$ & 0.67 & 0.75 & 0.92 \\
$\mathrm{He}$ & 0.141 & 0.142 & 0.182 \\
$R S$ & 2.281 & 2.604 & 2.628 \\
$\mathrm{~N}_{\text {mature }}$ & 0.022 & 0.037 & 0.088 \\
$\mathrm{Ne}$ & 34.7 & 64.3 & 60.3 \\
$s^{2}$ & 125.5 & 138.2 & 54.6 \\
$l$ & 7.92 & 8.31 & 5.22 \\
$A$ & 1575.7 & 1735.6 & 685.2 \\
\hline
\end{tabular}

N1: number of sample individuals within transects; N2: number of additional sample individuals from the neighboring 3-ha (TSU), 27.5-ha (SAN) and 100-ha (SOI) areas; $P l$ : proportion of polymorphic loci. He: expected heterozygosity; $R S$ : allelic richness; $N_{\text {mature }}$ : density of mature individuals in transect $\left(20 \mathrm{~cm}<\mathrm{DBH} \mathrm{ha}^{-1}\right) ; \mathrm{Ne}$ : effective population size; $\sigma^{2}$ : variance of the dispersal distance; $l$ : gene flow distance; $A$ : genetic neighborhood area.

Table 3. - Spatial autocorrelation (Moran's $I$ ) for common alleles.

\begin{tabular}{|c|c|c|c|c|c|c|c|c|c|c|c|c|c|c|c|c|c|c|}
\hline \multirow[b]{3}{*}{ Common allele } & \multicolumn{6}{|c|}{ TSU } & \multicolumn{6}{|c|}{ SAN } & \multicolumn{6}{|c|}{ SOI } \\
\hline & \multicolumn{6}{|c|}{ Distance class } & \multicolumn{6}{|c|}{ Distance class } & \multicolumn{6}{|c|}{ Distance class } \\
\hline & $0-10 \mathrm{~m}$ & & $10-20 \mathrm{~m}$ & & $20-30 n$ & & $0-10 \mathrm{~m}$ & & $10-20 \mathrm{~m}$ & & $20-30 \mathrm{~m}$ & & $0-10 \mathrm{~m}$ & & $10-20 \mathrm{~m}$ & & $20-30 m$ & \\
\hline $6 p g-b$ & - & & - & & - & & - & & - & & - & & -0.002 & & -0.002 & & -0.008 & \\
\hline Aap- $a$ & 0.002 & & -0.008 & & 0.022 & $* *$ & 0.006 & & 0.004 & & -0.027 & $*$ & 0.026 & $* *$ & -0.043 & $* *$ & -0.023 & $*$ \\
\hline Amy2-c & - & & - & & - & & 0.013 & $*$ & -0.011 & & -0.021 & & - & & - & & - & \\
\hline Amy2-e & -0.002 & & -0.004 & & -0.004 & & - & & - & & - & & 0.025 & $* *$ & -0.025 & $*$ & -0.019 & \\
\hline Dia-c & -0.001 & & -0.080 & & -0.002 & & 0.032 & $* *$ & -0.012 & & -0.023 & & 0.060 & $* *$ & -0.011 & & -0.078 & $* *$ \\
\hline Fum- $b$ & 0.050 & $* *$ & -0.020 & $* *$ & -0.044 & $* *$ & 0.014 & $*$ & -0.060 & & -0.002 & & -0.003 & & 0.004 & & 0.004 & \\
\hline$G d h-b$ & - & & - & & - & & -0.001 & $*$ & -0.001 & & -0.003 & & - & & - & & - & \\
\hline Got $1-c$ & -0.004 & & -0.010 & & 0.017 & $* *$ & -0.006 & & -0.004 & & 0.002 & & 0.010 & * & -0.016 & & -0.030 & \\
\hline Got3-b & - & & - & & - & & - & & - & & - & & -0.004 & & 0.001 & & -0.004 & \\
\hline Pgi-d & 0.089 & $* *$ & -0.037 & $* *$ & -0.060 & $* *$ & 0.008 & & -0.016 & & -0.013 & & 0.048 & $* *$ & -0.009 & & -0.058 & ** \\
\hline Pgml-a & -0.007 & & 0.006 & & -0.018 & & 0.054 & $* *$ & -0.046 & $* *$ & -0.044 & $* *$ & -0.005 & & -0.005 & & -0.004 & \\
\hline $\operatorname{Pgm} 2-c$ & 0.027 & & -0.024 & & -0.026 & & 0.018 & $* *$ & 0.001 & & -0.017 & & 0.038 & $* *$ & -0.052 & $* *$ & -0.012 & \\
\hline
\end{tabular}

$* * p<0.01, * p<0.05$. 
for eight alleles within the 0-10 $\mathrm{m}$ distance class was greater at SOI than at TSU and SAN. There were six significant positive values of Moran's $I$ at SOI, five at SAN and two at TSU.

\section{Estimating parental candidates for juveniles}

We estimated both pollen and seed parent candidates for seedlings $(\mathrm{DGH}<1 \mathrm{~cm})$. Among the candidates, $85.0 \%, 100 \%$ and $10.9 \%$ of seed parents and $95.8 \%$, $100 \%$ and $13.9 \%$ of pollen parents were estimated to lie outside the transect at TSU, SAN and SOI, respectively. The exclusion probabilities of the first parent were $0.308,0.437$ and 0.452 for TSU, SAN and SOI, respectively. Due to being not able to specify single parent for offspring, we could not calculate the exclusion probability of the second parent. The gene flow distances $(l)$, variance of dispersal distance $\left(\sigma^{2}\right)$, the genetic neighborhood area $(A)$ and $N e$ were shown in Table 2.

\section{Discussion}

\section{Genetic diversity in northernmost beech forests}

The average $H e$ of the northernmost natural beech populations at TSU and SAN were 0.141 and 0.142 , those were different from the Utasai population (0.223) in the same region (TAKAHASHI et al., 2002). TAKAHASHI et al. (2002) compared the genetic variation at Utasai with that of the Mt. Kurikoma population in northern Honshu; parameters were similar between these two populations, suggesting that the Utasai and Kurikoma populations had similar degrees of genetic variation. In addition, TOMARU et al. (1997) compared values from populations all over Japan, and obtained an average beech $\mathrm{He}$ of 0.187 . The isolated beech forests at northernmost (TSU and SAN) indicated low heterozygosity than SOI in the continuous beech distribution area. Proportions of polymorphic loci $(\mathrm{Pl})$ at three forests (TSU, SAN and SOI) were $0.67,0.75$ and 0.92 , respectively (Table 2). The lower values of $P l$ at two isolated beech populations (TSU and SAN) reflected the population size, and $P l$ of TSU was smaller than SAN. These results suggest the effect of genetic drift in distribution front, and this effect reflected population size.

Genetic variation of the northernmost secondary beech population (SOI) in continuous beech distribution area was not different from those of other regions within the distribution range of Siebold's beech (TOMARU et al., 1997), although heterozygosity of SOI was lower than the Utasai population in the same region. This result suggests that artificial disturbance in recent past affect to genetic diversity of northernmost beech population.

\section{Differences in genetic structure between three beech forests at the northernmost range}

The size class structures differed greatly between natural beech forests and secondary forest (Fig. 2). There were many individuals smaller than the $10 \mathrm{~cm}$ in $\mathrm{DBH}$ size class in TSU and SAN, the number decreased with size classes. In contrast, the size structure at SOI was unimodal, indicating the predominance of mid-sized individuals (Fig. 2). This unimodal distribution in size structure is attributable to simultaneous regeneration, following a strong disturbance of the forest stands (e.g. Ohsawa 1991), which is always a characteristic of secondary forests (KIKUZAWA et al., 1982; KAMITANI et al., 1986; TAKAHASHI et al., 2000; TSUKAHARA et al., 2004).

The density of mature ( $\mathrm{DBH} \geq 20 \mathrm{~cm}$ ) beech individuals was much higher in SOI than TSU or SAN, reflecting a successful regeneration. Individuals of middle-size classes were maintained in the population, but the maximum size in SOI was smaller than that in the TSU and SAN populations. TAKAHASHI et al. (2000) demonstrated the effects of forest lumbering on the within-population genetic structures of two beech stands (secondary and primary) with contrasting past historical backgrounds. Genetic variability was significantly lower in the secondary stand, and the genetic structures of these two stands were strikingly different. TAKAHASHI et al. (2000) suggested that the differences in genetic structure would likely influence succeeding generations. CESPEDES et al. (2003) have compared forest genetic diversity after pasture abandonment of $6,9,15$, and 20 years. In mature forests of the dry forest species, Swietenia macrophylla (Meliaceae), a much higher genetic diversity was found in the older stand. In contrast, results of this study have indicated that genetic variability $(\mathrm{He}$ and $R s$ ) is higher in SOI than in TSU and SAN.

The density of mature beech trees $(\mathrm{DBH}>20 \mathrm{~cm})$ was higher at SOI (176 individuals $\mathrm{ha}^{-1}$ ) than at TSU (44 individuals $\mathrm{ha}^{-1}$ ) and SAN (74 individuals $\mathrm{ha}^{-1}$ ), and the values of $l$ at SOI were smaller (5.22 $\mathrm{m}$; Table 2$)$ than at TSU (7.92 m) and SAN (8.31 m). The number of significant positive values of Moran's I was higher at SOI (six) than at TSU (two) and SAN (five) (Table 3). Because SOI had a higher density of mature individuals, the gene flow distance was smaller, but spatial autocorrelation was higher, resulting in significant genetic substructuring within the population. The SOI forest might have been occasionally disturbed, and as a result, simultaneous regeneration may have taken place from a small number of mother trees.

In contrast, TSU and SAN had a lower density of trees, forming an isolated natural beech forest stand. The values of $l$ were larger $(7.92 \mathrm{~m}$ and $8.31 \mathrm{~m}$ in TSU and SAN, respectively) than that of SOI, and the number of significant positive values of Moran's I was lower than that of SOI. Isolated and fragmented populations are inclined to develop extreme genetic substructuring, with much less genetic diversity (e.g. OHKAWA et al., 1998). Although TSU and SAN are natural isolated population with a lower density, gene flow distance was larger than that of SOI. The Ne was 60.3 at SOI, but 34.7 and 64.3 at TSU and SAN, respectively (Table 2), which is an indicator of the number of reproductive individuals in the genetic neighborhood, obviously influencing the maintenance of populations and genetic deterioration over time. In addition, there was different tendency over the natural beech populations.

In SAN, $R s$ values was higher (2.604) than TSU (2.281). Genetic parameters such as $A, l$ and $\sigma^{2}$ were at similar between SAN and TSU (Table 2). However, $\mathrm{Ne}$ was larger (64.3) in SAN than TSU (34.7). The distribution area of beech was larger in SAN than TSU, and the density of mature trees was higher in SAN than TSU. 
This result suggested that the size of Ne might contribute to the maintenance of $R s$ value in the northernmost beech forest.

Parameters of genetic diversity and genetic dynamics among regeneration process reflecting the population size and disturbance regime

KitAMURA et al. (2008) compared the genetic variation of several small isolated beech populations at the Noto Peninsula in Japan, indicated that population size reflected genetic variation. In this study, northernmost isolated small population (TSU) indicated the lowest parameters of genetic diversity ( $\mathrm{Pl}, \mathrm{He}$ and $\mathrm{Rs}$ ) in three populations (Table 2). Population size of TSU is the smallest; density of mature individuals is 0.022 , and area of population is smallest (3-ha). In contrast, SOI which has high density of mature individuals and widely area of population indicated high genetic diversity. These parameters of genetic diversity changed with population size.

Despite being a northernmost isolated population, TSU and SAN obviously have maintained a substantial genetic variability through regeneration processes. These two beech populations are also the northernmost isolated beech forest stands, also containing additional canopy tree species. Practically, TSU and SAN have a lower density of mature beech individuals than SOI. This difference in mature tree density contributed to genetic dynamics, which caused the difference in effective population size (Table 2). These population aspects (population size and mature tree density) may contribute to population vulnerability during the expansion process of the beech populations. Present northernmost beech populations are the distribution front of the beech distribution range, therefore, it is important to clarify population maintenance in distribution expansion. Results of this study indicated slightly lower genetic diversity at the northernmost isolated beech populations, yet the data suggest that the genetic diversity of offspring in this natural forest will be restored by larger gene flow distances. The beech populations at the distribution front seem to increase their genetic diversity readily through regeneration by outcrossing, and such genetic processes contribute to the genetic diversity and maintenance of robust populations in the distribution front.

\section{Acknowledgments}

We extend our thanks to Professor T. KoHYAMA for critical reading of the manuscript and his advices. We also thank C. Yonebayashi, A. KOYAMA and T. SHIRASAKI for their help in the field. This research was partly supported by the Environment Research and Technology Development Fund (S-8) of the Ministry of the Environment, Japan and Research Funds from a Kuromatsunai Natural Science Research Grant.

\section{References}

Cespedes, M., M. V. Gutierrez, M. Holbrook and O. J. RocHA (2003): Restoration of genetic diversity in the dry forest tree Swietenia macrophylla (Meliaceae) after pasture abandonment in Costa Rica. Molecular Ecology 12: 3201-3212.
Comps, B., D. Gomory, J. Letouzey, B. Thiebaut and R. J. PETIT (2001): Diverging trends between heterozygosity and allelic richness during postglacial colonization in the European beech. Genetics 157: 389-397.

CRAWFORD, T. J. (1984): The estimation of neighborhood parameters for plant populations. Heredity 52: 273-283.

Duncan, R. P. and G. H. Stewart (1991): The temporal and spatial analysis of tree age distributions. Canadian Journal of Forest Research 21: 1703-1710.

DAVIS, B. J. (1964): Disk electrophoresis II: method and application to human serum proteins. Annals of New York Academy for Science, 121: 404-427.

GOUDET, J. (2002): FSTAT, a Program to estimate and test gene diversities and fixation indices, version 2.9.3.2. University of Lausanne, Lausanne. Switzerland. Available from URL: http://www2.unil.ch/popgen/softwares/ fstat.html/. [cited 29 November 2005]

IGARASHI, Y. (1994): Expansion of Fagus crenata in Hokkaido. Forest Tree Breeding of Hokkaido 37: 1-7. (in Japanese).

KAMITANI, T. (1986): Studies on the process of formation of secondary beech forest in a heavy snowfall region (III). Seed production in secondary beech forests with six different diameter classes. Journal of Japanese Forest Society 68: 447-453 (in Japanese with English summary).

KaWANO, S. and K. Kitamura (1997): Demographic genetics of the Japanese beech, Fagus crenata, at Ogawa Forest Preserve, Ibaraki, central Honshu, Japan. III. Population dynamics and genetic substructuring within a metapopulation. Plant Species Biology 12: 137-155.

Kikuzawa, K., T. Asai, M. Fukuchi, N. Misui and E. MisuTANI (1982): Structure and growth of deciduous hardwood stand in Hokkaido (II). An analysis of stand in Azuma town. Bulletin of the Hokkaido Forest Experiment Station 20: 63-68. (in Japanese with English summary).

Kitamura, K., M. KobaYashi, J. Kodani and Y. YadA (2008): Genetic diversity of small isolated remnant beech (Fagus crenata) populations in the Noto Peninsula. Annual Report of Interdisciplinary Research Institute of Environmental Sciences 27: 23-33.

KITO, N. (2003): The northern limit of a beech forest and its historical consequences. SHINRINKAGAKU 37: 46-50. (in Japanese; the title was translated by the authors).

KIтO, N. and F. TAKIMOTO (1999): Population growth and migration rate of Fagus crenata during the Holocene in southwestern Hokkaido, Japan. Quaternary Research 38: 297-311 (in Japanese with English summary).

KoBAYASHI, M. and S. WATANABE (2003): Stand structure of northern bound population of Fagus crenata, located at Tsubamenosawa, Hokkaido, Japan. Bulletin of Geoenvironmental Science 5: 1-23 (in Japanese with English summary).

Marshall, T. C., J. Slate, L. E. B. KruUk and J. M. PemBERTON (1998): Statistical confidence for likelihoodbased paternity inference in natural populations. Molecular Ecology 7: 639-655.

MorAn, P. A. P. (1950): Notes on continuous stochastic phenomena. Biometrika 37: 17-23.

Mousadik, E. A. and R. J. Petit (1996): High level of genetic differentiation for allelic richness among populations of the argan tree (Argania spinosa (L.) Skeels) endemic to Morocco. Theoretical and Applied Genetics 92: 832-839. 